\title{
EU cooperation in the field of security - wishful thinking or a real possibility
}

https://doi.org/10.19195/2083-7763.10.8

\section{Abstract}

This article deals with the possibilities regarding cooperation in the field of security within the EU. This issue is discussed in the context of the social, economic and political aspects of this phenomenon. This article presents, among others, attempts made in this respect at the earlier stages of European integration. Referring to the existing possibilities in this field, it was indicated that the development of cooperation in the area of security within the EU should not consist only in imitating NATO's activities, but much more in taking actions which are complementary to them and innovative, and which are also well adapted to the European situation. The issue of EU security is treated in this article in the broad sense of this term, which is particularly important in the context of contemporary threats related to globalisation and rapid climate change.

Keywords: security, cooperation, threats, European integration, globalisation

\section{Introduction}

Security has become a fashionable concept, to which great importance is attached, nowadays. The word 'security' comes from the Latin 'secures', and means 'secure' or 'safe'. The need for security belongs to the most of basic human needs, appearing from the beginning in important sociological and psychological theories. The appearance of these in the context of families, clans, tribes, and in the end, of states, clearly shows the importance of this problem at different levels of human existence. However, a serious problem is associated with the fact that the security of some is often connected with a threat to others. 
Unfortunately, security seems to be a rare state of affairs. One must establish and protect it. Analysing the history of mankind, it should be noted that it is rather conflicts, wars, and various war-like events related to conflicts, e.g. famines or diseases, that are 'normal'.

\section{The first experiences of military cooperation in Western Europe after the Second World War}

The first attempts to build security structures in Western Europe were made in the spirit of confrontation between communism and Western democracy. In 1949, at the initiative of the United States, NATO was formed, and the response to this was the formation of the Warsaw Pact, with the USSR at its head. However, permitting West Germany to join this Western alliance was met with resistance; it was particularly strong in France. The horrors of World War II's experience ${ }^{1}$ were too vivid to ignore when formulating the defence policy of the countries of Western Europe. With great resistance, being aware of common threats and with the help of the United States, the countries of Western Europe accepted the need for military cooperation.

An important role in this respect was played by the process of integration of France, Germany, Italy, the Netherlands, Belgium, and Luxembourg, which had been initiated by the famous speech by Robert Schuman on 9th May, 1950 (the so-called Schuman Declaration). Thanks to this, and on the basis of the Treaty of Paris, signed in 1951 by the representatives of these countries, the European Coal and Steel Community (ECSC) was established.

In connection with this integration movement, an attempt was made in the past to create a 'European army'; this occurred in 1954, although, in principle, the step was supposed to be Franco-Western cooperation. The events that followed, known as drawing up the 'Pleven plan', were an attempt to accelerate the creation of a Western European defence community that was related to the Cold War, and especially the war in Korea (1950-1953). During the confrontation between the United States and its allies on the one hand, and the USSR, China and their allies on the other, French Prime Minister René Pleven announced in 1950 his plan, ${ }^{2}$ which foresaw the creation of a European army (these joint armed forces were to include troops from France, West Germany, the Netherlands, Belgium, Luxembourg, and Italy) under the command of a 'European Minister of Defence'. However, the Pleven plan was finally rejected by the National Assembly of France.

${ }^{1}$ J. Hirst, The Shortest History of Europe, Brecon 1999, pp. 181-193; B.H. Liddell Hart, History of the Second World War, London 1970, pp. 669-745; W.L. Shirer, The Collapse of the Third Republic, London 1970, pp. 495-921.

2 'The Pleven plan' was the French reaction to the American call for the rearmament of the Federal Republic of Germany.

Forum Socjologiczne 10, 2020

(C) for this edition by CNS 
It should be remembered that the initiator of military cooperation in Western European countries was the United States, interested, because of the Cold War, in the increase of the defence potential of its European allies. The situation changed in this respect in the face of Stalin's death and the end of the Korean War. In addition, NATO's development gave rise to the conviction that this US-dominated organisation is the optimal guarantee of security in this part of the world.

In the light of known facts, one should not despair because of the failure of the European Defence Community. It would have been dominated by the colonial interests of France and other countries of the Old Continent. It should be remembered that it was a period in which colonial empires still existed, and the process of decolonisation caused many tensions and bloody conflicts. At the same time, there was a tendency in different European countries to take joint actions to defend their interests; the largest and most significant of this took place in 1956, when France and the UK together attacked Egypt (co-operating with Israel in the act of so-called 'tripartite aggression') in defence of their influence on the status of the Suez Canal.

In the light of known facts, military collaboration between countries in Western Europe may have led them into 'colonial ventures'. It would not have been in agreement with the peaceful nature of the creation of the European Community. Under these circumstances, rejecting the creation of the European Defence Community by the National Assembly of France can be seen as a 'happy coincidence'.

Analysing the logic of the history of Franco-German collaboration, it should be noted that, in 1954, there seemed to be little chance of reconciliation; the history of the Second World War was still too fresh in the memory, and war experiences were too painful. In addition, the 'community of interest' was still not strong enough. It should also be remembered that, at that time, France had more common interests with the United Kingdom than with the FRG. ${ }^{3}$

Regarding the military aspect of US-France relations, the situation was complicated after the latter left NATO's military structures in 1966/1967. Also, the NATO troops and headquarters located in France had to be withdrawn from the territory of this country.

This decision, taken by Charles de Gaulle, weakened the cohesion of NATO on the one hand, and, on the other, gave France more freedom under bilateral relations.

The history of the Pleven plan has its positive side. The attempt to communicate on defence issues by countries that stood on opposite sides during the Second World War, irrespective of the final end of this initiative, deserves recognition, and was a step that allowed greater reconciliation in the following years, especially, between France and West Germany.

${ }^{3}$ R. Cole, A Traveller's History of Germany, London 2004, pp. 269-282. 


\section{Beginning of the EU security policy in an integrated Europe}

Thinking about the security policy in terms of Eastern and Western Europe became possible only after the fall of communism and the extension of Western integration to other countries, including many ex-socialist ones. Although discussions on common security within the integration process lasted for a long time, no concrete steps were taken. The situation began to change in the course of strengthening ties between member states. As a result of this, many interesting initiatives were taken, for example, on the basis of the Treaty of Maastricht, ${ }^{4}$ the Common Foreign and Security Policy has been established and, as the result of the Lisbon Treaty, ${ }^{5}$ the EU's Common Security and Defence Policy $(C S D P)^{6}$ came into existence.

This policy is implemented by $25 \mathrm{EU}$ member states. As part of the CSDP, many overseas operations have already been undertaken (over 30 since 2003), by using military as well as civilian instruments; ${ }^{7}$ during them, valuable experience has been gained.

An important initiative has been the creation of 'European military unions,' for example, the European Corps (Eurocorps) and the European Gendarmerie Force. It should be noted that these units, despite being European, retain their strong national character. Additionally, in 2002 the decision was taken to use NATO potential (assets, structures, and mechanisms) for the implementation of the European Security and Defence Policy goals.

A step in the direction of the creation of European security structures was the establishment of the European Defence Agency in 2004 in order to broaden the possibilities of reacting to emergency situations.

On 11th December 2017, the Council organised Permanent Structured Cooperation (PESCO) ${ }^{8}$ PESCO is participated by 25 EU member states: ${ }^{9}$ Austria,

${ }^{4}$ Signed on 7th February, 1992 and entered into force on 1st November, 1993.

${ }^{5}$ Signed on 13th December, 2007, and entered into force on 1st December, 2009.

6 'The Common Security and Defence Policy (CSDP) is an integral part of the Union's Common Foreign and Security Policy (CFSP)[1]. The CSDP is framed by the Treaty on the European Union (TEU). Article 41 outlines the funding of the CFSP and CSDP, and the policy is further described in Articles 42 to 46, in Chapter 2, Section 2 of Title V ('Provisions on the Common Security and Defence Policy'), and in Protocols 1, 10 and 11 and Declarations 13 and 14. The particular role of the European Parliament in the CFSP and CSDP is described in Article 36 of the TEU,' http:// statewatch.org/news/2017/jan/ep-factsheet-common-security-defence-policy-1-17.pdf/27.07.2019 (access: 21.11.2019).

7 The first two missions took place in 2003 in the former Yugoslavian Republic of Macedonia and in the Democratic Republic of the Congo.

8 "WHAT IS PESCO? It is a legally binding, ambitious and inclusive framework to deepen defence cooperation among the EU Member States that are capable and willing to do so. It was introduced by the Lisbon Treaty." https://www.consilium.europa.eu/media/32081/qa_pesco.pdf/201.07.2019 (access: 21.11.2019).

${ }^{9}$ Cf: "It is not the first time that the EU has attempted to place soldiers of national armies under a common command. In the last decade an EU combat group was created, which can be quickly

Forum Socjologiczne 10, 2020

(C) for this edition by CNS 
Belgium, Bulgaria, the Czech Republic, Croatia, Cyprus, Estonia, Finland, France, Germany, Greece, Hungary, Italy, Ireland, Latvia, Lithuania, Luxembourg, the Netherlands, Poland, Portugal, Romania, Slovenia, Slovakia, Spain, and Sweden. ${ }^{10}$ The planned goals of PESCO include, a. o., the development of European capability and training in the area of security. ${ }^{11}$

An important event was the creation of the European Defence Fund in 2017. The budget, announced in 2018 by the European Commission, for 2021-2027 amounts to a total of 13 billion Euro.

A tangible result of the security policy are also common projects in the field of European military equipment. The creation of the European arms industry can be an important step towards strengthening the subjectivity of our continent, and brings benefits not only in terms of security, but also in those of economics. There are already some achievements in this field. An example of European efforts to increase the technological capabilities of European countries associated in the EU can be the production of the Eurofighter by a European consortium. This interesting project is worthy of attention. In addition, there is a growing awareness of the need to unify defence equipment that EU countries use. There is also a big problem in EU countries with differing weapons; its gradual unification would be an important step towards improving the EU's military potential. ${ }^{12}$

The EU also has several small, but promising, achievements in the field of creating 'security structures.' These include joint missions in the defence of peace, the creation of mixed military units, the cooperation of military and paramilitary organisations, establishing contacts and maintaining them through various European institutions working for security and collaborate in the framework of joint projects, like the Eurofighter. In addition, the awareness of campaigning is becoming more and more common.

deployed as an intervention force in conflict areas. But these so-called "battle groups" have never been used. This time, however, PESCO is intended to create an instrument that actually proves to be viable for the participating countries. 23 countries - excluding the UK, Ireland, Denmark, Malta and Portugal signed the founding document for permanent cooperation earlier this month. The cooperation is meant to be finalised at the EU summit in mid-December." https://www.euractiv. com/section/politics/news/european-military-cooperation-how-to-defend-europe/19.07.2019 (access: 21.11 .2019 ).

10 https://www.consilium.europa.eu/media/32081/qa_pesco.pdf/20.07.2019 (access: 21.11.2019).

11 On 19th November, 2018, the Council established the civilian Common Security and Defence Policy (CSDP).

12 Cf: 'PESCO is not meant to compete with NATO, but rather encourage common missions and interconnect national armaments industries. At present, Europeans are providing 178 different weapon systems. In comparison, the US uses 30. Through stronger cross-border cooperation Europeans want to make sure that they can maintain pace in the global technology race of the future. In addition, it is simple budgetary concerns that force closer armaments cooperation. "We want to expand cooperation because armaments are becoming more expensive," says Jean-Jacques Bridey, the chairman of the defence committee in the French Parliament.' https://www.euractiv.com/section/politics/news/ european-military-cooperation-how-to-defend-europe/19.07.2019 (access: 21.11.2019).

Forum Socjologiczne 10, 2020

(C) for this edition by CNS 
The EU creates the possibility of using financial support while creating defence programs in the aspect of the build-up of industrial infrastructure; an example can be 'The European Defence Industrial Development Programme' (EDIDP).

\section{NATO versus the EU}

In recent times, there are many voices indicating that the North Atlantic Treaty Organisation is outdated. From the European point of view, this does not seem to be true, although some formulations of US President Donald Trump, directed against the EU, even question the reason for the existence of NATO itself. He has accused the European members of the organisation of spending too little on defence. 'I said a long time ago - that NATO had problems,' Trump told The Times and Bild. 'Number one, it was obsolete, because it was, you know, designed many, many years ago. Number two - the countries aren't paying what they're supposed to pay'. ${ }^{13}$ He suggested, by the way, that US support for allies should be dependent on the amount of their military expenditure. One should add to this the isolationist stance of Trump.

Paradoxically, the anti-EU rhetoric of Trump ${ }^{14}$ can help to spread the conviction in EU countries that, apart from NATO, also a European security system is needed. An important element that makes cooperation in the field of security more likely is the higher level of economic development attained by several European countries belonging to the $\mathrm{EU}$ and the ability to implement joint projects, also in the field of security.

\section{Creation of the EU s security approach}

Despite all efforts, the achievements hitherto made in creating a EU security system seem to be relatively modest. This fact is connected with the lack of understanding of the specific situation of the EU. Above all, one should be aware that the creation of the 'second NATO' does not make much sense. However, it should be noted that, at the same time, NATO's raison d'être was created during the Cold War and, as such, is not adequate for responding to contemporary threats; in this sense, both NATO-critics and President Trump seem to be right. However, we can be positive that the difference between the traditional operations of NATO and the changing situation and new challenges could determine the field of EU activities. ${ }^{15}$

13 https://thenewsrep.com/72685/trumps-attitudes-toward-eu-nato-lead-unprecedentedchanges-us-foreign-policy/21.07.2019 (access: 21.11.2019).

${ }^{14}$ I. Morris, War. What is it good for?, Croydon Cro 2015, pp. 332-393.

15 T. Berend, The History of European Integration, London-New York 2016, pp. 231-242. 
It would be a mistake to concentrate solely on the security provided by military power, ${ }^{16}$ although it is, undoubtedly, very important. The changes taking place in the world are too fast and too complex to allow one to be one-sided. Also, concerning the question of enemies, one should be flexible; historical experiences have proved that former enemies can become allies in certain situations. There are also scenarios in which certain countries compete in one area, while in others their cooperation is possible.

The emergence of new threats, ${ }^{17}$ such as political tensions ${ }^{18}$ and war in Ukraine, various types and forms of terrorism, migration crisis, ${ }^{19}$ but also the dangers associated with the pollution of the environment, ${ }^{20}$ diseases, climate change, etc., open up, at the same time, new opportunities for the EU. ${ }^{21}$ It seems reasonable to strengthen the European presence in NATO (still developing the rapid reaction force, unifying and standardising weapons and military equipment, and investing in the technical implementation of the armed forces), at the same time focusing on these security issues with which this organisation does not deal. Much more can be achieved dealing with these issues, which NATO does not deal with. In this spirit, the EU-NATO Joint Declaration, the European Defence Action Plan, seems to be formulated (2016), and the EU Global Strategy in the field of security and defence created. Also, the second declaration, which followed in 2018, bearing the title 'The Declarations,' welcomes the EU's efforts in terms of security and defence, which are complementary and not an alternative to NATO, ${ }^{22}$ and presents a similar 'philosophy'.

The list of elements (not directly military, but important for security) is long enough to constitute a significant challenge for the EU, which is not secured by NATO. For example, these include topics such as food, water, and energy provision, health protection, defence against populist movements, demagogy and organised crime, fighting terrorism, rational social policy, ${ }^{23}$ the cleanliness of

16 Cf. U. Beck, World at Risk, Polity, Cambridge 2016, pp. 140-159.

17 J. Sachs, The End of Poverty, Penguin Books, London 2005; M. Shaw, Civil Society and Media in Global Crises, New York 1996, pp. 347-368. Cf. S.P. Huntington, The Clash of Civilizations and the Remaking of World Order, London 1997, pp. 81-121.

18 Cf. R. Dahrendorf, Class and Class Conflict in Industrial Society, Stanford-California 1976, pp. 280-318.

${ }^{19}$ Cf. P. Zieliński, “The Education of the Vietnamese Minority in Poland, Poznań" Studia Edukacyjne 2014, issue 33, pp. 393-412. Cf. D. Acemoglu, J.A. Robinson, Why Nations Fail, London 2013, pp. 368-462; D. Murray, The Strange Death of Europe, London 2017, pp. 94-257.

20 J. Cavanagh, J. Mander, Alternatives to Economic Globalization, San Francisco 2004, pp. 1974; R. Janik, Political, Economic and Managerial Reflections on the Globalization Process, Częstochowa 2017, pp. 97-102.

${ }^{21}$ E. Trafialek, "Education towards demographic old age," [in:] Ekonomiczny, socjalny, ekologiczny kontekst współczesnych problemów międzynarodowych, Winnica 2010, pp. 304-318.

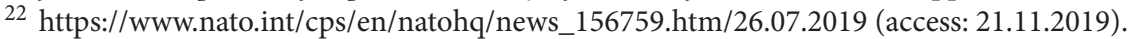

23 T. Pikketty, Capital in the Twenty-First Century, Cambridge-Massachusetts-London 2014, pp. 471-570. 
the natural environment, ${ }^{24}$ climate change issues, flood or fire prevention measures, transport safety, access to knowledge, information and education, economic security, etc. It should be mentioned that some of these problems have already been targeted. The implementation of joint civil projects increases the level of technical efficiency and significantly develops effective management techniques.

The broad understanding of 'safety approach' has much to do with sustainable development (a.o. in the form of sustainable security) and is of a permanent and human-friendly nature.

\section{Conclusion}

As it appears from earlier considerations, continental solidarity is a relatively new phenomenon. The European continent has experienced numerous wars in the past. Without a deep understanding of European history, the contemporary defence and security system of the EU cannot be created properly. The subject of security is not limited to the military aspect, although that is very important.

A new spirit of European self-confidence has an impact on the security issue.

Actions in this field create opportunities for innovation and embracing relationships as part of efforts to strengthen EU security. It is worth recommending to take advantage of the US experiences and creating in Europe a similar system of cooperation in the area of security between universities, using the Internet for this purpose. It would allow the creation of a - European Internet - which would be an extremely important step towards the empowerment of the EU in terms of this kind of cooperation, creating a valuable - communication infrastructure - for it. At the same time, countries associated in the EU have their own rich experience in the field of creating security systems. They also have contacts with various scientific and research centres, as well as with cultural organisations all around the world, which should be used to improve the global security system. In this context, it is important to realise that, in today's complex and dangerous world, the best way to achieve a stable state of security is to work together with others in different fields to solve human problems effectively.

\section{References}

Acemoğlu D., Robinson J.A., Why Nations Fail, Profile Books, London 2013.

Berend T., The History of European Integration, Routledge, London-New York 2016.

Cavanagh J., Mander J., Alternatives to Economic Globalization, San Francisco 2004.

Cole R., A Traveller's History of Germany, London 2004.

Court T. de la, Beyond Brundtland, New York 1990.

${ }^{24}$ M.B. Steger, Globalization, Oxford-New York, 2009, pp. 84-97; D. Johnson, C. Turner, European Business, London-New York 2016, pp. 242-249. 
Dahrendorf R., Class and Class Conflict in Industrial Society, Stanford-California 1976.

Hirst J., The Shortest History of Europe, Brecon 1999.

Huntington S.P., The Clash of Civilizations and the Remaking of World Order, London 1997.

Janik R., Political, Economic and Managerial Reflections on the Globalization Process, Częstochowa 2017.

Johnson D., Turner C., European Business, London-New York 2016.

Liddell Hart B.H., History of the Second World War, London 1970.

Murray D., The Strange Death of Europe, London-Oxford-New York-New Delhi-Sydney 2017.

Pikketty T., Capital in the Twenty-First Century, Cambridge-Massachusetts-London, 2014.

Sachs J., The End of Poverty, London 2005.

Shaw M., Civil Society and Media in Global Crises, New York 1996.

Shirer W.L., The Collapse of the Third Republic, London 1970.

Steger M.B., Globalization, Oxford-New York, 2009.

Trafialek E., "Education towards demographic old age," [in:] Ekonomiczny, socjalny, ekologiczny kontekst wspótczesnych problemów międzynarodowych, Winnica 2010.

Zieliński, P., "The Education of the Vietnamese Minority in Poland, Poznań," Studia Edukacyjne 2014, iss. 33.

\section{Internet sources}

http://statewatch.org/news/2017/jan/ep-factsheet-common-security-defence-policy-1-17.pdf.

https://www.euractiv.com/section/politics/news/european-military-cooperation-how-to-defendeurope.

https://www.consilium.europa.eu/media/32081/qa_pesco.pdf.

https://thenewsrep.com/72685/trumps-attitudes-toward-eu-nato-lead-unprecedented-changes-us-

foreign-policy.

https://www.nato.int/cps/en/natohq/news_156759.htm.

\section{Kooperacja na polu bezpieczeństwa — myślenie życzeniowe czy realna możliwość}

\section{Streszczenie}

Artykuł zawiera rozważania dotyczące możliwości współpracy na polu bezpieczeństwa w ramach UE. Problematyka ta omawiana jest w kontekście społecznych, ekonomicznych i politycznych uwarunkowań tego zjawiska. W pracy ukazano próby podejmowane na wcześniejszych etapach integracji europejskiej. W nawiązaniu do istniejących możliwości w tej dziedzinie wskazano, że ewentualna współpraca w zakresie bezpieczeństwa UE nie powinna polegać na powielaniu działań NATO, lecz na podejmowaniu aktywności w stosunku do nich komplementarnych, innowacyjnych oraz dostosowanych do specyfiki sytuacji europejskiej. Zagadnienie bezpieczeństwa UE zostało w artykule potraktowane „szeroko”, co jest szczególne istotne w sytuacji występowania we współczesnym świecie zagrożeń związanych z globalizacją i zmianami klimatycznymi.

Słowa kluczowe: bezpieczeństwo, współpraca, zagrożenia, integracja europejska, globalizacja 